\title{
Capitalists and whalers: the makah Indians
}

\begin{abstract}
Historically the Makah organized themselves in small chiefdoms, whose society was stratified in aristocratic lineages, commoners and slaves. Status was ascribed by birth and validated by potlatching. Ruling class control was economic, political and ideological, although far from complete and not always effective. Things changed profoundly, however, in the mid-nineteenth century. After an epidemic and the 1855 treaty many slaves that were born in the tribe had purchased their freedom and a number of slave men and women married their former masters and mistresses. The children of such marriages were considered half slaves and the stigma of these ascendants has not yet disappeared and is matter of much gossip. Trading with the Euro-Americans opened the door to property and chiefly privileges, and being near the source of American power, the reservation agent, meant being also able to distribute favours. This change caused a number of problems in the old system of social and family status. In 1924 the United States granted all American Indian people citizenship and the right to vote, and in 1934 the Indian Reorganization Act (IRA) gave the Makah the opportunity to develop a tribal constitution and an elected government. The Makah stopped whaling in the early $20^{\text {th }}$ century. After more than a seventy years' gap, they petitioned the US government to represent them at the International Whaling Commission (IWC) after the grey whale was removed from the list of the endangered species. Although the Makah cannot be considered to hunt for subsistence, they can rely on the1855 Treaty of Neah Bay with the USA which explicitly safeguards their right to whale. Hence, the US delegation petitioned the IWC on behalf of the Makah 'cultural rights'. This move, however, created havoc among environmentalist groups and animal rights advocates, who boycotted physically the hunt. So far the Makah killed successfully only one whale out of the twenty in five years they had been permitted to hunt with a legal device and failed the 2000 and 2001 hunts. They also lost in the federal court in 2002 and 2004, killed illegally a whale in 2007 and are presently banned from whaling.
\end{abstract}

Most analyses of the Makah effort to revitalize whale hunting deal with the contrast between the 'ecological' Indian of green ideology, and the 'non-ecological' one the Makah supposedly represent in green activists' propaganda. Studies also deal with on the issues of authenticity, invented traditions, etc., but very few with the consequences of Makah neo-aristocratic restoration, supported by neo-whaling ideology as a tool of social control, if it succeeds in being federally recognized. This ideology, however, though accepted by most Makah and social scholars (in the name of political correctness, which emphasizes the uniqueness of specific and especially cultural, features, ${ }^{1}$ has been challenged by green activists and above all by the media and the public. I argue that most of those who are supporting a return to a non-denaturized form of 'traditional' government that is a posttraditional 'capitalist chiefdom,' put at risk both their property and civil rights.

Keywords: makah land, cultural, salish language, seagulls, tribe
Volume I Issue 4 - 2017

Sandra Busatta

Department of Anthropology, Italy

Correspondence: Sandra Busatta, Department of Anthropology, Italy, Email sandra@hakomagazine.net

Received: April 07, 2017| Published: July 19, 2017
Abbreviations: IWC, international whaling commission; IRA, indian reorganization act; MCRC, makah cultural and research centre

\section{The makah land}

The Makah, a southern Wakashan speaking people live at Neah Bay, a small reservation around Cape Flattery on the extreme north-western tip of the Olympic Peninsula, Washington State. Their name reflected this geographical location. In fact, they called themselves qwi-dich-cha-at, that is people who live near the rocks and the seagulls ${ }^{2}$ their current name is based on the Clallam maqa? that is People of the Cape, and it has been in official use since the 1850s. ${ }^{2}$ Anthropologist Ann M. Renker ${ }^{1}$ remarks elsewhere that

${ }^{1}$ Anthropologist A.M. Renker has worked for the Makah Cultural and Research Center as Director of the Makah Language Program and later, as the Executive Director of the facility. Since 1993, she has worked for the Cape Flattery School District, which supplies the public education services for the Makah Reservation. Initially Dr. Renker was the ESL teacher and coordinator of the bilingual education program till she moved into administration in 2002. She the Makah language was not used when the treaty was negotiated, so the government used the Salish language name for the tribe. The current name is supposedly an incorrect pronunciation of a Salish term that means 'generous with food,' but this interpretation is rather brand new and looks a bit self-serving. Eighteenth-century visitors ${ }^{2}$ knew them as the people of tutu-ts, "thundering", one of the three

has been the Markishtum Middle School and Neah Bay High School principal since 2005. She also wrote the IWC Reports representing Makah position about whaling: Whale Hunting and the Mahak Tribe: A Needs Statement in 2007 (IWC59/ASW/209) and 2012 (C: IIWC64\ASW \64-ASW 4) ${ }^{3}$

${ }^{2}$ John Meares, sea captain, entrepreneur, fur trader (b 1756?; d 1809), in 1788 sailed with 2 ships to Nootka, where he built a temporary trading post; in the spring of 1788 he anchored off the coast of Tatoosh Island. The Spaniards from New Spain, responding mainly to Russian activity in Alaska and worried by British activity in an area they claimed as theirs sailed into Neah Bay in 1790 and established a fort in 1792, which was abandoned after four months. In 1809-1810 a number of shipwrecked Russians and 'Aleuts' (probably Pacific Eskimos) were enslaved by the Makah and then ransomed by the British, a fate that was later shared by three shipwrecked Japanese in $1833 .^{2}$ 
thunderbird brothers, and the name of a powerful chief, Tatoosh, identified with the island off Cape Flattery. The Makah are considered the southernmost representatives of the Nootka tribes. ${ }^{3}$ Historically they organized themselves in small chiefdoms, whose society was stratified in aristocratic lineages, commoners and slaves. According to Colson, ${ }^{4}$ however, only their special legal status differentiated them from their non Indian neighbours $n$ the 1940s. First contacted ${ }^{4}$ in the late $18^{\text {th }}$ century, the Makah have been known since then as proud whalers, they stopped whaling in the early $20^{\text {th }}$ century.

In a territory experiencing winter storms and sunny, cool summers in the Boreal Rainforest, in pre-contact times the Makah dwelled in five independent villages Diya (Neah Bay), Biheda, Wayatch, Tsoojess and Ozette, linked by language kinship and common traditions, but which occasionally warred among themselves as well as against their neighbours. These villages were inhabited all the year long, but in summer some people moved to temporary residences at Achawat, Kydikabbit and Tatoosh Island. ${ }^{5,6}$ However as Renker and Gunther ${ }^{2}$ point out: "All the people of one village did not necessarily go to the same fishing sites. If a headman owned rights to multiple sites, he could divide the labour in his household to accommodate the need for groups at different sites."

The Makah 'tribe's had little unity beyond the local communities in the old times the five Makah villages probably never formed more than a very loose alliance in some occasion and it seems that the Ozette fought with the Cape Flattery groups. This 'war' seems to have been for the most part between the Ozette and a Neah Bay group with the other villages relatively neutral. ${ }^{7}$ Even the village unit, however, might be riven by feuds between members of powerful, rival families. Culturally, the Makah belonged to the Nootkans of whom they shared general subsistence patterns, social organization, ceremonialism and linguistic family (the Wakhashan family, of which they are the southernmost members), but they also shared some cultural features with their Salishan and Chimakuan neighbours. This was due to the Makah location as middlemen in the trade between the Lower Columbia River and Vancouver Island. The Nootkans consider themselves a single population because of the mutually intelligible linguistic variations as well as kin ties. ${ }^{8}$

Approximately A.D. 1500 an enormous clay slide buried part of the village of Ozette, a large multiseasonal community. At least four

${ }^{3}$ Captain James Cook who anchored in Nootka Sound on March 31, 1778, referred to the local Mowachaht and Muchalaht people as the 'Nootka' people, a name that was used until recently to describe all Nuu-chah-nulth speaking people and their language, the southern Wakashan. The Nootka live on the west coast of Vancouver Island, British Columbia, Canada and today they are organized into a tribal council consisting of representatives from about twenty local bands, such as the Chickliset, Ahousat, Ucluelet, etc. Some scholars, such as Arima (1983) have suggested three distinct geo-cultural zones: Northern and Central Nootka and Nitinat. The Makah, once divided into five small chiefdoms, live on the northwestern tip of the Olympic Peninsula, Washington State, across the Strait of Juan de Fuca, and are closely related to the Nitinat. ${ }^{4}$ Speaking of the relations between natives and outsiders, historians and ethnographers currently use the word 'contact' in lieu of the more biased 'discovery' and 'encounter', in order to describe the History of Contact. Actually, 'contact' is more neutral because it means 'to come in contact with' under whatever circumstances, shipwreck victims included.

${ }^{5}$ They are enrolled in the federally recognized Makah Indian Tribe of the Makah Indian Reservation. Tribe is a bureaucratic term borrowed from ethnography by the U.S. Bureau of Indian Affairs, but it has little to do with its ethnographical usage. The same is true for the term 'band', which is the Canadian equivalent. ${ }^{4}$ cedar plank houses were sealed into a deposit permanently saturated by surface water flow, which allowed outstanding organic preservation as well as unprecedented clarity in the recognition of cultural features. Archaeological excavations between 1970 and 1981 produced more than 50,000 artefacts and more than 100,000 pieces of associated faunal material. The prehistoric artefacts recovered from the Pompeii of the Northwest, as it is called by tourist guides, were preserved in the tribally-owned Makah Cultural and Research Center (MCRC). This tribal museum/cultural centre, opened in 1979, have become the centre of a Makah 'cultural renaissance.'

\section{Makah social organization}

The whaling culture of the Nootkan peoples on both shores of the Strait of Juan de Fuca in the pre-contact period was of central importance: not only it served subsistence and economic purposes, but it also fulfilled important social, spiritual functions. ${ }^{4,9,10}$ The aboriginal populations of the Northwest Coast, such as the Makah, were divided into a three class system: the ruling elite, the commoners, and the slaves $^{6}$. Status was ascribed by birth and validated by potlatching 9 and as MacLeod"11 (1929:95) put it, "the private ownership of the means of production, capital and land, made for the differentiation of labour classes within the community." Chiefs were owners of all resources, included beaches, fishing grounds and beached whales and commoners' exploitation of resources, such as salmon streams, was always at the chief's pleasure. Territories were bounded with markers and defended from intruders. Spanish scientist Moziño, in 1792, ${ }^{11}$ stressed the fact that "the chief of the nation carries out the duties of the father of the families, of king and of high priest at the same time. These three offices are so closely intertwined that they mutually sustain each other, and all together support the sovereign authority of the tsaises [chiefs]."As Moziño remarks further, the privileged relationship of the ruling elite with the supernatural continued in the afterlife. Nootkan hereditary chiefs were called Hawiih (pron. huwuhithl) in the north and chaachaa-bat' (pron. cha-cha-butuh) in the south.

As Renker (n.d.) sums up, ancient Makah people developed "a complex society which had many rigid rules that affected each individual. Each individual belonged to a family, which had specific rules that governed the behaviour of each member. In addition, each person had a ranking in his family, just like in the English royal family today. There was one individual, most likely a man, who governed each family and all other members were ranked relative to him. Only one person could occupy each numbered place of status and places would shift if someone died, did something terrible or decided to shift his alliance to another family. Unlike other northwest coast tribes, the Makah people could choose to associate themselves with either the mother's or the father's family, whichever would provide the

${ }^{6} \mathrm{~A}$ person who is enslaved because a victim of a slaving/war party, changes his or her status and his or her descendants's, because it becomes a non-person, a thing, an item of movable property, a slave. According to the ethnographical literature in the Northwest Coast there were three classes and society was divided into three tiers, aristocratic households, commoners and slaves. This is a modern Western point of view: for the indigenous peoples there were only two tiers, both divided according to rank. Slaves were not people and therefore could not be considered part of tribal societies (although they participated in it, actually), as much as a blanket cannot be considered a tribal member. A slave belongs to a category of goods; it is an item of movable personal property, such as blankets, coppers, wooden dishes, etc. The English word chattel, which defines movable properties, slaves included, comes from cattle to which slaves were equated in antiquity https://chs.harvard.edu/CHS/article/display/3895 
highest status. This situation allowed the Makah people to develop the concept of personal wealth and a system of owning songs, dances and resource areas long before European (capitalist) economies influenced the culture."

In sum, the highest ranking Makah male was the chief of an extended family: he owned all of his family wealth, both tangible and non-tangible: family crests, songs, dances, rites and costumes, as well as big houses, shellfish grounds, salmon and halibut fishing grounds, berry tracts, grass and shrub patches, beaches, harbours, caves as well as timbered areas. Ruling class control was economic, political, and ideological, although far from complete and not always effective. The commoners were more or less distant relatives of a chief, not in the direct line of descent; the descendants of younger sons, however, formed a sort of middle class, a group of lower ranking chiefs whose status was never stable and where shifts constantly occurred. The commoners were not "the owners of the fruit of their labour, except in a very small part". ${ }^{12,13}$ In fact, according to the Journal of the fur trader Alexander Mackenzie (1801: 374-75), ${ }^{14}$ no one could fish without the chief's permission, carry home more than one half or less of what he or she had caught (deer, shellfish, berries, etc.) nor build a house. Artisans were outside this obligation and were supported directly by the chief; a shaman's career, on the other hand, was one of the few means by which a commoner could acquire some prestige and wealth. ${ }^{9}$

Slaves were mostly prisoners of war and their children, although debt slavery also existed. Their place in the big plank house was by the entrance, and they were significant as trade objects, protective attendants, and sacrificial victims (Arima and Dewhirst 1990:400). Slaves primarily performed drudge tasks, went to war for their masters, paddled their whaling canoes, and punished reluctant or riotous commoners for them. Since a chief collected a tribute in kind of no fixed amount from the commoners exploiting local resources, the failure to pay the tribute could cause debt slavery. Makah slaves were banned from marrying free-born spouses, but lived in their houses and took part in social life. They defended their masters in combat and dispatched those suspected of casting evil spells over them by means of poison. Not even feasts of give-aways could mitigate the stigma or guilt of those once raided and eventually ransomed, especially if they belonged to the upper echelon of the Strait Juan de Fuca and Puget Sound tribes. ${ }^{13,14}$ The Makah stressed the importance of blood lines so much that any reference to slave ancestry was an insult to be wiped out with the offender's blood (ibidem:180). The stigma was still so important that, when I made my fieldwork in Neah Bay in the late 1990s-early 2000s, there was an area of the reservation where nobody in his right mind would build a house: it was the village where the descendants of the slaves freed by the 1855 treaty and high rank persons forced to sell themselves by family pressure to pay a debt once lived. ${ }^{7}$

Chiefs and their elite families did not engage in drudge labour, but only in more prestigious activities, such as whaling, although some lesser chiefs engaged also in sealing. Only the inferior class of people or the slaves were occupied in fishing, while the more noble occupation of killing the whale and hunting the sea otter was performed by the chiefs and the warriors. Also fishing was ranked: according to Gibbs $(1877)^{15}$ only the upper portion of them attained the dignity of whalers, a second class devoted themselves to halibut, and a third to salmon and inferior fish.

Although the Treaty of Neah Bay in 1855 had abolished slavery, and the USA had obliged the Makah to give up war, they went on buying slaves, mostly children, from other tribes, even if they were

${ }^{7}$ For an exhaustive survey of slavery among the Nootkans ${ }^{13}$ treating them better than before. Things had changed profoundly, however, in the mid-nineteenth century: at first the Makah and the Clallam had opposed to white settlement, but in 1853 the smallpox nearly wiped out the Makah, killing chiefs and slaves alike. It was brought by two Makah who had worked in San Francisco. The Makah were so desperate that they "offered, in return for a cure, to become the slaves of John Hancock, a white trader in Neah Bay. The gesture reveals their plight, for they had frowned on his presence there [...] for years the Makah believed whites had put the disease in bottles and buried it in the sand". ${ }^{14}$

After the epidemic and the treaty many slaves that were born in the tribe had purchased their freedom, and in more than an instance slave men and women had married their former masters and mistresses. ${ }^{5}$ The children of such marriages were considered half slaves and the stigma of these ascendants has not yet disappeared and is matter of much gossip. It was the son of a slave, however, "the head chief Tsekauwtl, whose expertise as a whale man had catapulted him into the leadership position", ${ }^{16}$ who was to guarantee the whaling clause to the Makah in the Treaty of Neah Bay. He announced that "he wanted the sea that was his country" and Governor Stevens replied that the President of the United States "knows what whalers you are, how you go far [out] to sea, to take whales. He will send you barrels in which to put your oil, kettles to fry it, lines and implements to fish it". ${ }^{16}$

Although Northwest Coast societies were small relative to classic chiefdoms and, most importantly, they were not agricultural, they relied on an efficient storage technology and their local populations were dense. 'Ritual promotion' elevated particular lineages to a higher segmentary position within the genealogical structure by the demonstration of important ties to the supernatural. Winter ceremonies and most secret societies were a prerogative of the aristocracy. Feasts, initiations and potlatches were the occasions which offered chief frequent opportunities to perform important songs and dances in front of a large audience validating his privileges and power.

Among the Makah, as well as the other Northwest Coast tribes, songs were and still are personally owned. Goodman ${ }^{17}$ is correct when she observes that "the songs owned by a chief helped him maintain his position. It was essential that a chief owned many songs and that he used them often on the proper occasion. Members of the community knew precisely which songs belonged to a particular chief; when sung at public ceremonies, these songs renewed and strengthened the power of that chief." The privileged relationship of the ruling elite with the supernatural continued in the afterlife, because the aristocracy, the commoners and the slaves went to different after worlds. Commoners were allowed to own few songs and of lesser significance than those owned by the chiefs and the slaves could only perform dances and songs owned by their masters if they were ordered to. ${ }^{17}$

Potlatches $^{8}$ were less common when native-produced goods accumulated slowly, but became frequent after the Makah entered

${ }^{8}$ The potlatch, from the Chinook word Patshatl, functioned to confer status and rank upon individuals, kin groups and clans and also to establish claims to names, powers and rights to hunting and fishing territories. Wealth in the form of utilitarian goods such as firearms, blankets, clothing, carved cedar boxes, canoes, food and prestige items such as slaves and coppers were accumulated by high-ranking individuals over time, sometimes years. These goods were later bestowed on invited guests as gifts by the host or even destroyed with great ceremony as a show of superior generosity, status and prestige over rivals. A great potlatch might last for several days and would involve feasting, spirit dances, singing and theatrical demonstrations. In addition to its economic redistributive and kinship functions, the potlatch maintained community solidarity and hierarchical relations within and between, individual bands and nations." http://www.thecanadianencyclopedia.ca/en/article/potlatch/18-28 especially on the Nootkan potlatch ${ }^{8,29-31}$ 
the capitalist economy. Potlatches were given primarily to transfer chiefly privileges and status to successors; they were ceremonial feast traditionally featuring seal meat or salmon to commemorate an important event, such as the death of a high-status person, but expanded over time to celebrate events in the life cycle of the host family, such as on occasions such as the birth of a child, the start of a daughter's first menstrual cycle, funerals, weddings and so on or the Wolf ritual. The potlatch was also used as a face-saving device by individuals who had suffered public embarrassment. Before the inclusion of the natives in the maritime fur trade 9 , gifts included storable food such as dried Oolichan (candlefish) or candlefish oil, canoes and slaves, but not income-generating assets such as resource rights. The potlatch reached its most elaborate development among the southern Kwakiutl from 1849 to 1925.

Although the main purpose of a potlatch was not the occasion itself but the validation of claims to social rank, Nootkan potlatches rarely featured competition, shaming of rivals, property destruction (included the killing of slaves), or hostile behaviour, according to Drucker. ${ }^{8}$ In sum, they were different from the better known potlatch feasts of the more northern Kwakiutl tribes, who fought with their wealth, according to the words of a Kwakiutl. ${ }^{18,13}$ As Renker (n.d.) puts it: " These events provided the means for the ancient Makah culture to standardize important information about marriages, deaths and the ownership of names, songs, dances and other ceremonial and economic privileges. Business that affected the ownership or use of these items was conducted publicly; witnesses were paid to remember a transaction and provide reports in the future. The potlatch provided ancient Makah with a means to publicly document and recount important events to succeeding generations in absence of a writing system." When I attended a potlatch in Neah Bay in the late 1990s every guest went home with a mug and some leftover food in one or more containers. The guests' arrival by boat was welcomed on the beach by a high-ranking woman from a whaler family, wearing her "onion dome" hat depicting successful whale hunts of her ancestors, and singing a welcome song giving permission to land, answered by a song by the guests in the canoe. The guests' seats and gifts (mostly banknotes) were ranked according to their social importance: hosts and guests in all their finery wore the symbols of their families' heritage (hats, masks, crests painted or embroidered on their smocks, dresses, mantles and dancing shawls, etc.), sang songs and danced dances owned by their families, alone or with one or two relatives, even if some songs and dances were owned by a larger group of performers.

\section{The makah enter the capitalist economy}

The introduction of a European cash economy during the heyday of the sea otter fur trade and the later advent of commercial whaling and sealing created a shift in emphasis away from whaling and associated social mechanisms. ${ }^{2}$ In 1870 Swan $^{5}$ probably makes the clearest statement on the changes in Makah chieftainship: "Formerly the tribe had chiefs and head men whose word was law. The strongest man, who had the most friends or relatives, was the head chief, but of late years there has been no head. In every village there are several who claim a descent from chiefs of note and call themselves chiefs and owners of the land, but their claims are seldom recognized, excepting that they are considered as belonging to the aristocracy and are superior to the mis-che-mas or common people, or the Kot-hlo or slaves. [...] The dignity of chief or head man can be attained by ${ }^{9} \mathrm{Cf}$. James R. Gibson. ${ }^{32}$ anyone fortunate enough to accumulate property. An instance of this kind is the case of Sekowt'hl, the head chief of the tribe, who was appointed such by Governor Stevens at the time of making the treaty."

The maritime fur trade of the first half of the 19th century opened the door to more property and chiefly privileges and being near the source of American power, the reservation agent meant being also able to distribute favours. This change caused a number of problems in the old system of social and family status. But even more drastic changes were to come: the 1852 smallpox epidemic decimated the Makah population and caused the abandonment of Biheda. Fatalities further disrupted privileged lineages and people died without transmitting ceremonial rights or privileges through a potlatch, while the accompanying rituals and songs went lost. In some way the 1855 treaty and the smallpox epidemic had the same effects on the Makah as the French revolution and the Terror had on the French Ancient Regime. Even if a Restoration was made after Napoleon things were not the same and the New France had become a fully capitalist country. The same can be said of the new Neah Bay, made up of the previous five independent villages. After the Makah went under the charge of a government agent and saw that no distinction was made between slaves and free, "the old prejudice against labour is wearing away, and men and women, with the exception of a few among the old chiefs, are willing to engage side by side in such work as requires to be done for the agency". ${ }^{5}$ Moreover, children of every rank were compelled to go to school, in order to learn the basics of "civilization" useful to become new American citizens.

In 1924 the United States granted all American Indian people citizenship and the right to vote, an event which is still commemorated in the annual Makah Days. In 1934 the Indian Reorganization Act (IRA) gave the Makah the opportunity to have more control on their reservation. The Makah Tribe accepted the IRA and signed the Makah Constitution in 1936, which provided for an elected five member Tribal Council. Each member serves a three year term, no more than two seats are voted upon in any given year, and a new Tribal Chairperson is elected by the five council members each year. Despite all these changes, however, in retrospect the tribal elder Edward Claplanhoo was able to assert to Collins ${ }^{16}$ that "the early contact with Anglos was all to the benefit of the Makas."

For the Northwest Coast, Ruyle ${ }^{11}$ distinguishes a Pre-Contact period up to about 1785 , with intertribal trade, slave raiding and social classes, a Fur Trade period (1785-1860), with a possible intensification of trade and social stratification favored by the new capitalist economy and access to international markets, and an Acculturation period after 1860 , characterized by epidemics and demographic collapse, major Euro-American settlements, treaties and disappearance of the classes while the rank remained. Although Ruyle's analysis according to a Marxist model is interesting, I do not think social classes disappeared after the Neah Bay Treaty of 1855. On the contrary, I maintain that social stratification was transformed from pre-capitalist to capitalist and the elite of an aristocratic chiefdom was replaced by a capitalist class.

In his study about the Makah reservation between 1855-1933 Collins ${ }^{16}$ remarks that historians have justly focused much attention on Makah whaling activities, but pelagic sealing actually constituted the tribe's primary revenue source in the late $19^{\text {th }}$-early $20^{\text {th }}$ centuries. Sealing was so lucrative for the Makah and West Coast native hunters that their traditional whaling expeditions virtually ceased as a 
consequence. Commercial sealing began at Neah Bay as a symbiotic relationship between Makah and American fishermen. In 1869 white schooner owners hired tribal members for first time to accompany them to the Bering Sea. Often earning handsome salaries, Makah hunters received two-thirds of the catch, and schooner operator's one-third. Although several agents had urged that the Indian Office allocate funds to purchase a schooner to replace the Makah canoes, Washington's obtuse bureaucrats refused to act and doing this unwittingly favored the birth of the first Makah entrepreneurs. In 1880 a Makah became the proud owner of a small schooner, the tribe's first and by 1893 the Makah owned ten 25- to 50-ton craft. Makah profits soared: in the 1980s an elderly Makah remembered: "My mother said we (Makah) always had gold coins in our pockets." ${ }^{33}$ Similarly, 75-year-old Frank Smith, son of a Makah who owned interest in a schooner, recalled his father's saying that on "paydays seal hunters had to pack their money home in satchels because their pockets couldn't hold it all (interview by Collins, Feb. 10, 1995.) In the 1890s Americans from Port Townsend typically worked for the Makah to pilot their schooners on trips to the Bering Sea and Japan. When commercial sealing ceased to be viable, the Makah turned to halibut fishing; although halibut fishing did not bring the Makah as lavish an income as sealing, it allowed the tribe to remain mostly independent from federal assistance. Halibut fishing faded out in the $1950 \mathrm{~s}$, replaced by salmon fishing and remained a primary occupation until the 1970s. Sealing remained an economic activity for some tribal members. Fish canneries hired both men and women. Fishing and fish canneries were not the only source of income for the Makah: they traveled to north Puget Sound to pick strawberries and blackberries and went to the Yakima Valley to harvest hops. Women made and sold traditional basketry, which brought in several thousand dollars annually. In the 1920s Makah began selling timber stumpage and many found employment with a lumber Company. The federal government became another source of jobs: tribal members built roads, gun emplacements and a breakwater. ${ }^{16}$ To one degree or another until 1928, however, tribal members continued to whale and to subsist at least partially upon whale meat, blubber and oil, exhibiting a dogged determination to engage in their accustomed work despite adverse conditions. ${ }^{34}$ When in the early 1890 s the Indian agent prohibited potlatches on the reservation, the Makah simply transferred their rituals to Tatoosh Island, where they had long maintained a fishery. ${ }^{2}$ Given the ideological importance of whaling for social relations inside the tribe and with other whaling tribes, this is not a surprise.

\section{Makah political decision making process}

At Swan's times, in mid-19th century, all matters of importance were submitted to a council, which is held whenever anyone gives a feast or during the time of the ceremonials of the tamanawas. Before the introduction of the IRA elected tribal council, as Riley pointed out, the situation was confused by the fact that the chiefs were appointed by the government; the issue was also a somewhat emotional one for 'chiefly' positions were much desired and much disputed by older members of the community. Things changed little after the introduction of the IRA tribal elective council and the American-style democratic process. Densmore ${ }^{6}$ referred that the "chief used to hold meetings, or councils, in his house, inviting only the leading men of the village. They were careful not to let outsiders know of these meetings and every transaction was kept secret until it was disclosed. Then the men were at liberty to tell others if they wished to do so."

The political decision making process is still very opaque today and far from the democratic standards to which we are accustomed in the Western countries. For instance, the decisions made by the tribal council during the "politics of the hunt," as Sullivan ${ }^{35}$ called the councillors' and the hunters' families' political manoeuvring during the 1999 successful whale hunt, were as such secret. "The tribal council issued a memo that nobody was to talk to the newspapers. They wanted to banish people who opposed whaling from the reservation. This fear of banishment really stopped a lot of people from helping us," says Dotti Chamblin, whose ancestors include Chief Seattle and Ba-ba-sit, who died in 1907 and was one of the last whalers. Also the letter sent to the Peninsula Daily News by a group of elders opposing the hunt speaks of the fact that "the whale hunt issue has never been brought to the people to inform them" (Ides et al. 2000). Anti-whaling elder Alberta Thompson confirms: "In pushing forward with their plans to kill whales, the Tribal Council did not go to the people and ask their opinion. This was not the traditional way of Makah people" (1997) actually the Council behaved as traditional chiefs had always had, in secret, but she as well as other dissenting Makah, have assimilated a "social contract" notion of government. In fact, as we have seen in Densmore, the chief used to hold meetings of councils in his house with the leading lineage headmen and they were very careful to keep secret both meetings and decisions, until it was time to implement them. According to Thompson and other dissenters the members of the Tribal Council did not consult tribal elders who were not in the Council and did not ask ordinary people's opinions on the whaling issue and its political feasibility, did not look for a majority consensus by means of a poll, a referendum either formal or informal or a public meeting. Apparently, it was all very hush-hush. From the dissenters' words it appears that there is no formal opposition in the Tribal Council and the leading families negotiate through their relatives elected in the Council until some kind of agreement is reached, and then they communicate their decisions, which cannot be discussed by the tribal populace, but only complied with.

Although they may have a hidden political agenda, Western-style democratically elected representatives publicize their programs and meetings through the media (newspapers, TV news and talk shows, social media), as part of the relationship between an elected politician and the electors/taxpayers $\mathrm{s} / \mathrm{he}$ represents. In their interviews Thompson and other dissenters were opposing, unfavourably for the latter, a western-style decision process to that of the tribal government and they did not considered the workings of the Council the traditional way of decision making, which actually it is. The fact is that a number of tribal people is not happy with it any longer and would prefer a more (at least formally) transparent decision making.

Although the elite families control tribal elections, there are some ideological problems about elections in general. As Adam Shewish, head of the Sheshaht Band of the Nuu-chah-nuulth put it, "One trouble with elections is that they come every two years. Everybody is waiting, waiting: Who's to be chief? And of course it takes a year to know the ropes and then in one more year, why you're out. With the hereditary system you know you're in for life. I don't have to be elected to let the people know who I am". ${ }^{33}$ Hereditary positions hopefully save a person from the bites of gossip, especially at election time: in 1942 Colson "found that everyone in the village accused others of being low-class and not entitled to speak for the Makah or to hold up their heads in front of really good people". ${ }^{4}$ In the old days the chiefs' status was validated by their control over economic resources and over their subordinates. This status was periodically demonstrated through ceremonial prerogatives, the tupat, exhibited in potlatch feasts. Today anyone can pay his way by earning money and can give feasts. Lines of ancestry are blurred by intermarriage and connections 
outside marriage with Whites and other Indians. Gossip and scandal are aimed also at the tribal officials and represent an important subtext before and during the annual Makah Days.

\section{The grandmothers' war or gossip business as usual}

In the early 1950s Elizabeth Colson wrote:"from amid this welter of boasts, insults, charges and counter charges, the investigator emerges with an amazement that each family is able to have faith and pride in its own blue blood" and: "The history of the tribe itself alters from informant to informant as it is used to highlight the career of a particular family group". ${ }^{4} \mathrm{~A}$ 'good name' is the most vital social possession as well as the most vulnerable commodity. Therefore, the individual Makah counteract the risk of revealing the secrets of community life and organization to outsiders, cheating and lying and at the same time, tattles with the anthropologist in order to counteract their neighbours' gossiping.

Gluckman, ${ }^{36}$ on the other hand, remarks that in the specific situation of the Makah, "it seems also that their biting scandal is used to maintain the principle of equality between all members. The Makah fought a Washington State law to protect the breeding of fish, by claiming the right to fish out of season in a certain river on the grounds that they fished there when the Treaty of the reservation was signed. To win their case, they had to admit that one family had hereditary rights in the river. They preferred to lose their case. Makah ship, through the weapon of scandal, keeps them in practice equal." Further, Gluckman suggests that "Makah gossip does not show merely that general interest in the doings and the virtues and vices, of others, which characterizes any group. The gossip passes beyond this stage and becomes vicious scandal, aimed at demonstrating that the other parties are not worthy to be Makah. The different groups and individuals in the tribe fight an unceasing battle to demonstrate their own true Makahship, as against the failures of others to attain Makahship. But this involves them in a continual process of remaining Makah, which (as Colson says) gives high importance to the scandalizing itself, as a mechanism for maintaining the Makah as a group encysted in the American nation, whose other members are excluded from this war of scandal."

A similar problem is currently faced by the MCRC: in fact, while they are trying to have items of cultural significance returned by the US museums under the NAGPRA, ${ }^{10}$ families and individuals are battling over ownership notions (communal in the MCRC or private), as well as access to the information connected to the artefacts and therefore to the rights and privileges these artefacts guarantee to their owners. Disputes between families are so heated that, at the moment, the issue has not found a satisfactory solution. Moreover, the 'recognition' of the use of pre-contact artefacts which 'triggers' the elders' memories can be subject to the suspicion of self-serving within the game of status enhancing.

Colson ${ }^{4}$ wrote that the Makah had brought the art of verbal denigration to a high peak. The problem is: what happens when the game of slander, which the Makah delight in playing with supreme technical skill, leaks out of the borders of Neah Bay and appears in the breaking news of the global village? In December 1996 a first rank Native American writer, Chickasaw Linda Hogan and Seattle writer Brenda Peterson wrote three long articles on The Seattle Times about

${ }^{10}$ Public Law 101-601, Nov. 16, 1990, known as Native American Graves Protection and Repatriation Act their interviews with Makah elders "who are breaking the silence and speaking out against their tribe's return to whaling." "The story of the Makah and the grey whale may turn out to be one more painful story of corruption, of inexperienced whalers in battle with environmentalists, of the oppressed who in turn oppress their own people, of a conflict between some traditionalists who speak for old values and business leaders who negotiate contracts and have the capacity to hire publicrelations specialists to help promote their whaling interests with the media, nationally and internationally. The Makah story goes further than this, into the territory of intimidation and harassment of the old women who, in earlier times, would have been the respected voice of their people. Why would the old grandmothers frighten the business leaders of a tribal nation?". ${ }^{33}$ A furious Tribal Chairman Ben Johnson replied. "Apart from the fact that Linda Hogan betrays her own Indian heritage by presuming to comment on tribal issues that are none of her business, she has only embraced two elder women who do not happen to agree on the whaling issue. This (Makah Whaling) commission is composed of hereditary families representing timeless cultural interests essential to our identity as a whaling First Nation". ${ }^{37}$

Although the Sea Shepherd Conservation Society and the animal rights activists enlisted the dissenting elders among their army, this was not the case, with the possible exception of Alberta Thompson and this more as a reaction to the repressive actions of the Council than else, even if she shows some influence of animalist humanization of the whales. The new shape of gossip and status is now played less on innuendos about slave blood tainting your genealogy and more on your knowledge of tradition. Actually it is the same old story told in a more modern way: in fact, if someone does not know how to behave in a traditional way, it means that he/she is so low class that he/she knows nothing about Makah traditions. The Allabush sisters Isabelle, Ruth and Margaret married in whaling families, the Ides, the Claplanhoos and the Irving's; their grandmother, Susie Napoleon was drafted to paddle a whaling canoe belonging to her family when the crew was a person short. "Time changes things. No living Makah has ever whaled, but they are doing what they want. I was gratified that some of the younger members of the tribe have questioned the hunt and I was hurt that despite my standing as a tribal elder, I was not consulted. To me, they didn't get any knowledge from the elders and that what's made me very unhappy. They can't get enough fish for the potlatches, but they are only after the whale." The perceived insult is that, if nobody consulted her it is because they have no traditions to tell, because they belong to the lower class, while the poison is in Margaret Irving's last words (1999). In fact, she argues that those posing as great chiefs' heirs actually are lazy enough, stingy enough that their guests go away hungry from their pitiful potlatches. In sum, they use the whaling issue as a smoke curtain to hide their poor performance as (tribally elected as well as hereditary) chiefs. "I don't care about the whale. We went without the whale all this time. Nobody even knows how to prepare the meat" added Isabelle Ides (1999).

The three sisters and other four elders wrote a letter to the Peninsula Daily News, in a space provided by environmental organizations, where they voiced their opposition to the hunt. Among the other things they wrote: "We believe they, the Council, will just shoot the whale and we think the word 'subsistence' is the wrong thing to say when our people haven't used or had whale meat/blubber since early 1900s. For these reasons we believe the hunt is only for money. They can't say "traditional, spiritual and for subsistence" in the same breath when no training is going on, just talk." 
Sidney Bowechop, a retired logger, said in 1999: "If the whale is wasted we'll draw even more criticism. These people around here aren't going to eat it. If Mac Donald's fixes it or Burger King makes a whale burger, they will eat it. But they don't have the foggiest idea how to eat what the old people used to eat." Sidney is afraid that people may throw away the meat of the hunted whale, since they are not used to eat food prepared according to ancient and forgotten traditions. If this would happen, the media that were supporting the animalists' cause would portray the Makah in an even more negative way that is as people that killed a gentle giant, a sensitive marvellous creature only to waste its meat. Many readers had sent letters full of hate to the papers and the animalist militants in their TV interviews were busy to portray the pro-whaling Makah as a kind of cannibals. However, if only out of curiosity, many people ate the whale hunted in 1999, butchered on the beach and distributed according to rank, even though many children, not used to the taste, spat it in disgust. The Makah had eaten the meat of a beached whale the year before; Greg Colfax told me that, since the meat was almost rotten (the whale beached in another the reservation and it took three or four days before the Makah could get it), most did not eat it and he confessed it was rather disgusting. I ate whale meat at a Japanese restaurant in Oslo, Norway and I can say the taste is not for everybody: not bad, but is a rubbery, chewing thing similar to no other meat I have eaten. I suppose Sydney had the episode of the beached whale in mind when he spoke about likely wasting of whale meat, but he also wanted to point out that nowadays people is used to eat hamburgers. Trenchantly he says that the Makah had been Mac Donaldized and has neither the cultural knowledge nor the taste for traditional food, whale meat in particular.

Alberta Thompson points out that when it was necessary to survive by hunting whales and seals it was also necessary for the Makah to "walk over 90 miles to collect berries. Today we go to the grocery store. Today there are some who wish to see a return to whaling. There is no similar desire by these same people to go long distance berry picking; there is much talk of killing, yet no talk of respecting traditions, honouring our elders or being prepared for the sacrifices, the cleansing ceremonies, the prayers and the rituals" (1999). Alberta is the only one that has spoken of class differences in a modern way: "The killing of these whales will serve only to make more money for the people on our reservation who already have money. Problems of drugs and alcohol will continue as the disparity between haves and have-nots widens" (1998). On the whole, however, she states her dissent in terms of traditions genuine or spurious: "To start whaling again without re-establishing the spiritual aspect of these traditions is to dishonour our ancestors."

The contest is about whaling as a demonstration of traditional knowledge and therefore of rightful claims to one's family status. Vivian "Libby" Lawrence, a former Tribal Council chairperson, demonstrates an elite perspective when she says: "I am content to see my family's whaling traditions reside in the past. Tribal identity needs no boast from a harpoon. The family doesn't need whaling to tell them they are Makah. We know who we are and what we are. My great-grandfather was James Claplanhoo; one of the tribe's last whaling chiefs. I don't need a whale killed to be any more Makah that I have been my entire life. We have never lost our culture. Whaling won't make a difference in my life" (1998). The whaling faction, of course, is made of nouveau riches, needing to demonstrate they "have a culture," she implies.
Helma Wards, traditional head Arnie Hunter's mother, who had many relatives in the 1999 whaling canoe crew, on May 17, the day of the successful hunt, stayed in bed as a whaler's first wife used to do to keep the prey willing to die and told her deed to everybody. Others preferred to rely on old, well oiled insults hurled at their enemies: Marcy Parker, together with Makah Fisheries assistant director Dave Sonnes and Fisheries director Daniel Greene, called Alberta Thompson "a slave" from the Vancouver Georgia Strait. Alberta Thompson, Marcy Parker and Dan Greene had been the protagonists of a contest of "truths" at the IWC meeting in Aberdeen, Scotland. Alberta had gone there with her cousin, Dottie Chamblin, who had tried for a position on the Tribal Council several times, but had always been unsuccessful. "Do you know how many relatives they (the Council have? Said Chamblin to The International Harpoon (1996) Families are loyal. Friends are loyal." "They are all related to them that makes them all the more loyal. Added Thompson, describing a typical patronage system, People are afraid of voting against Council members because they are afraid of losing their jobs. The Council is by far the largest employer in the community, with 200 people on their staff. Even if the voting is done secretly, in such a small community it is known who people vote for." Thompson used a previous incident of an entangled grey whale that was brought ashore as a proof that the Makah did not know how to catch a whale or eat it. "The worst meat they have ever had. Most of the meat went into the dump; the garbage collectors had a hard week after the whale was butchered." "It tasted like something between beef and venison" Marcy Parker told to the press and Green replied to the dump charge: "I am at the dump once a week and I didn't see any meat there. The smoked meat was delicious. We boiled some blubber at the beach and the kids ate it like candy. The texture is just like the boiled octopus which is common in our diet".

\section{The chief and the whale or the nootkan body politic}

During the 1960s and 1970s a pan-Nootkan or 'independence' movement developed, whose basic goals were the establishment of a positive Nootkan identity, socio-economic improvement, and a complete control by the Nootkans of their own affairs (Arima and Dewhirst 1990). The discovery of pre-contact Ozette and the opening of the Makah Cultural and Research Center (MCRC) at Neah Bay, as well as other archaeological projects on Vancouver Island, helped support the articulating of a neo-whaling ideology. The most sophisticated theoretician in public probably is Huu-ay-aht traditional chief Tom Mexsis Happynook, ${ }^{38}$ whose name means Gray Whale Hunter, Founding Chairman of the World Council of Whalers, Brentwood Bay, British Columbia, Canada, but its apotheosis may be considered the exhibition Huupukwanum-Tupaat. Out of the Mist Treasures of the Nuu-chah-nuulth Chiefs ${ }^{39}$ held at the Royal British Columbia Museum in Victoria, BC in 1999. I contend that this neowhaling ideology is a hegemonic theoretical tool in order to restore a hierarchical social organization, which I call neo-aristocratic, by arguing that a return to the 'authentic core' of Makah and Nuu-chahnulth traditions, that is whaling, once practised only by the aristocratic heads of the households, is indispensable for the healing of the social problems of the reservations.

According to chief Happynook, ${ }^{40}$ "whaling within Nuu chah nulth society was the foundation of our economic structure. It provided valuable products to sell trade and barter. In essence it was our national bank. Whaling strengthened, maintained and preserved 
our cultural practices, unwritten tribal laws, ceremonies, principles and teachings. All of these elements were practiced throughout the preparations, the hunt and the following celebrations. Whaling strengthened and preserved our spirituality and is clearly illustrated through the discipline that the Nuu chah nulth hereditary whaling chiefs exemplified in their months of bathing, praying and fasting in preparation for the hunt. The whale strengthened our relationships with other nations and communities." Hence, Happynook argues that Nuu-chah-nulth type of liberal democracy should be "based on the premise that the hereditary system is a responsibility bestowed upon the hereditary chiefs by the creator. Understanding where you fit within the universe, the web of life, the environment, the ecosystems, the society and the community creates different forms of democracy which has been given by our creator and administered through the people by the hereditary chiefs". ${ }^{41}$

Chief Happynook's praise of whaling as the basis of Nootkan society is very similar to the political thought of other hierarchical societies. Whaling is a highly ritualized affair, which codifies people's place and rank in a Nootkan community; moreover, the cutting and the distribution of the meat reinforce the analogy between the whale and the chief, as we will see later. The analogy between the whale's body and the social body is an organic metaphor that in Western political thought is called the body politic. But metaphors to communicate political statements about political structures of phenomena are not a monopoly of the Europeans or the Makah. Examples include the human body, a machine, a ship of state, animal behaviour and family relations, the sun and the planets, etc. In native America, for example, the jaguar was a very important metaphor. ${ }^{42}$ In Asia the rituals the emperor performed kept Earth in correspondence with Heaven and yin and yang in balance.

In particular, the analogy of the body politic ${ }^{11}$ is the perception and elaboration of correspondences between society or the state and the individual human body. In its simplest form, a 'natural' society is one which functions in a manner similar to the human body. ${ }^{43}$ Winter ceremonies and most secret societies were a prerogative of the aristocracy. Feasts, initiations and potlatches were the occasions which offered chief frequent opportunities to perform important songs and dances in front of a large audience validating his privileges and power. In Nootkan thought the whale is the symbol of the body politic: whales represented both fabulous resources and fatal adversaries.

${ }^{11}$ The first examples of the analogy between the political body and the human body in the Old World date back to India, but its principles were articulated for the first time by the Greeks. Aesop's apologue of the Belly and the Limbs became explicitly political in Roman times and was later applied to Christian doctrine. In the middle Ages, the analogy of the body was developed in an important way: the Church became the mysticum atque politicum corpus of which the pope is the head, and the kings and emperors are just the limbs.

Organic analogies serve as a powerful support in all political controversies and in the late Middle Ages an extension of idea of the mystical body to the king's body illustrates convincingly the growing awareness of the nation state, especially in England. In the sixteenth and seventeenth centuries, the analogy persists and in many cases becomes a vehicle of social criticism. A growing skepticism, however, together with widespread materialism and the successful notion of social contract, destroyed this traditional analogy. Calvin supplanted the idea of the church as mystical body by putting the emphasis on the covenant, a typical example of which is the Mayflower Compact of the Pilgrim Fathers, where 'body politic' has become synonymous with 'political entity'. The 'body politic' persists in the nineteenth century as a dead metaphor, until positivism began to apply biological evolutionism to political institutions and social sciences, bringing it back to the notions of society.
Death was also connected to whales: in fact slaves were occasionally sacrificed in whaling magic, corpse's manipulation was involved in the secret rituals and men were sometimes lost at sea during the hunt. A whale's death-bringing powers, as well as its life-giving substance, were analogous to those of a chief. ${ }^{44}$

The idea of cooperation within the body politic also emerges in the distribution of whale meat, which is iconic of social organization. Nootkan chiefs distributed food and each portion was a function of the traditional rights of its recipient, in a manner similar to the feudal titles and rights in Medieval Europe. The whale feast defined the organic community, the Nootkan body politic, which was always local, because as whale meat was limited, so an alliance of villages was always provisional. ${ }^{44}$ Moreover, by providing a body shared by the villagers according to their rank, the whale provided also a template of social and political organization, that is, its functionally related parts mapped the relations of classes in Nootkan society. Jerry Jack, a Mowachaht-Muchalaht chief, once said: “Our people didn’t just go down the beach and cut a piece of meat off. There was a certain cut for each chief" (The Daily News (Halifax) 1/11/98: no page). Huuay-aht Willie Sport ${ }^{39}$ explains: "We want you to understand what the whale represents to us. When the whale was cut, it represented every inch of our chief's territory, every cut had to be precise. You could not cut into another chief's portion, because that meant part of his Hauutli hohoothly (territory) was being cut off." Nootkan polities had a first-ranking chief and a number of lesser ranking chiefs, whose seats and territories were hereditary. Thus the whale represented not only the community, but also an organization chart of the elite, whose respective ranks have become murky, and a subject of incessant gossip. .45

Harkin $^{44}$ argues that the chief is, symbolically, always a whale, because he is a giant among men as the whale is a giant on the seas. Nevertheless, the chief actually reincarnates in a killer whale, which gives a good idea of the place of the chief in the metaphorical foodchain and casts a gloomy shadow on the chief's relationship with his community. Chiefs are similar to the cetacean killers of whales, which are wolves transformed into sea predators; according to Nootkan myths and rituals, such as the very important Wolf Dance, they are sea wolves: this notion was revivified in 2004 when a young killer whale, Luna or Tsux'lit, was recognized by chief Mike Maquinna as the reincarnated hereditary chief of the Mowachaht-Muchalaht First Nation, his father Ambrose Maquinna, who had died three days before Luna's arrival in Gold River. ${ }^{46}$ Wike $^{12}$ remarks that, alongside the figure of the beneficent chief who was priest and good provider of food for his people, there was also the chief of the secret societies, the terrible wolf of the Tlukwana (Wolf Ritual), whose impressive imagery was violent and thanatotic, a cannibal devourer who was not a priest but a dreaded shaman, who held potentially coercive power through chattel slaves and bullies who supported him.

One diagnostic quality of the chief is his territorial and resource prerogatives and obtaining whales is one dimension of this. The association between the whaling medicine (magic) and the establishment of a chiefly lineage is strong, to the point that, as Harkin ${ }^{44}$ asserts, successful whaling can be read as equivalent to the existence of a chiefly polity: as a matter of fact, the words hauuthi (territory, pr. huhoothli) and hawilh (chief, pr. huwuheeh) are etymologically related. Natural resource ownership and management are currently the paramount issues both in Vancouver Island, British Columbia, where the Nuu-chah-nulth live and in Washington State, where the Makah 
reside. The Declaration by the Hawiih (pr. Huwuheeh) of the Nuuchah-nulth Nations ${ }^{39}$ gives no room to misunderstandings: the chiefs, not the people, are the rightful owners of their territory and they claim full control of all lands, waters and resources. They claim that their authority has not been extinguished by any treaty or superseded by any law, and in the negotiations with the governments of Canada and British Columbia they want "to reach agreements and/or treaties which will recognize and reaffirm our ownership and governing authorities over our respective Huautli (territory)." By doing this Canadian authorities would give up to a common law tradition developed from the Magna Charta onward.

\section{Neo-aristocratic restoration and neo-whaling ideology}

Colson ${ }^{4}$ discovered, in the 1940 s, that some individuals wanted to project the old class system into present social life, even though they admitted that there were no slaves any longer. They thought, however, that those with slave blood could still be placed in a class subordinate to the others and virtually deprived of civil rights such an idea has not been abandoned by their children, but has been modernized within a neo-whaling ideology as cultural rights. The construction of a hegemonic notion of culture by the dominant elite in Neah Bay, which is made up of 23 families that can trace back their ancestry to whaling chiefs, was not without controversy, especially during the period 1997-2005. Hegemony can never be considered as guaranteed and is exercised through two modes of social control: coercive and consensual. Most Makah dissidents have been silenced with the threat of expulsion from the reservation; die-hard Alberta Thompson lost her job, her dog was killed and her daughter's rights were revoked. It cannot be denied; however, that consensus on the restoration of whaling is also very real. Hegemonic thought, in fact, is constructed at school by the ruling class: as American officials taught Makah children to be good American citizens and useful members of capitalist society, so the whaling faction teaches its values in the local school, since most of them have been or are teachers and headmasters.

In order to understand the project of the neo-aristocratic restoration of the Makah ruling class, I use the concepts of neo-tribal capitalism, neo-traditionalism and retribalization that Elizabeth Rata $^{47}$ forged as theoretical tools drawn from Marxist thought in order to explain the re-emergence of a pre-democratic Maori tribal elite in recent decades in New Zealand, where this group asks for social structures based on kinship to be incorporated at institutional level. Although Rata's model refers to the Maori situation, which is more recent than the process of neo-tribalization of the Native Americans that began in the 1930s, this model is useful to understand the internal dynamics of the Makah. Rata, in turn, develops Jonathan Friedman's ${ }^{48-50}$ analysis of ethnic revivalism: this scholar identifies a strong functional relationship in global-local dialectics between worldwide capital flow changes and changes in the construction of identity and cultural production that characterizes ethnic revivalism from the late 1960s to the present. The Makah ruling class in times of crisis has provided security and even salvation ${ }^{45}$ to the Makah community by means of a neo-traditionalist ideology that I call neo-whaling ideology.

Rata describes neo-tribal capitalism as characterized by the lack of private property of the means of production. The Makah, however, have become an incorporated tribe in 1934: before that time they had known the private property of tangible and intangible goods (lands, waters and knowledge), first according to the rules of a gift society ${ }^{51}$ and since the 1880 s according to a regime of capitalist accumulation. As a matter of fact, the most prominent supporters of neo-whaling ideology are trying to transform the means of production commonly owned by the incorporated tribe into privately owned ones according to hereditary status and genealogy. They are trying to have their neoaristocratic reform federally recognized and social relationships based on kinship incorporated at institutional level.

Friedman ${ }^{48}$ comments that the combination of tribal organization and accumulation and capitalist transfer are important to understand how a local movement reorganizes within the global system. The class structure that appears to be emerging is such that those who control capital in the tribe introduce wage labor among lower-ranking relatives and former slaves, transforming them into a subordinate class. A second division emerges according to this pattern among those who have access to tribal property and federal funds and those who do not have it: the jurisprudence of the new corporation increases conflicts within tribal society while people struggle to define their genealogical rights to the means of production. The effects of Makah neo-tribalization within the dominant elite are described by Colson ${ }^{4}$ and Tweedie; 45 Colson also describes the manipulation of tribal citizenship criteria in order to exclude many Makah and non-Makah (spouses, children or grandchildren) from access to tribal resources.

A third process, which Rata and Friedman describe for Pacific societies, but which is also visible in our case, is the formation of an intermediate class based on the control of specialized knowledge in the matrix that links the new traditionalist class to the cultural apparatus of the state. These intellectuals have played a key role in the construction of the neo-whaling ideological hegemony and work as consultants inside and outside the tribe. Indeed, the Makah elite and its non-Indian supporters believe that a culture can be recovered ${ }^{12}$ and traditions may be 'lost and found,' to paraphrase the title of $\mathrm{Coe}^{48}$ based on a phrase of the Makah artist Greg Colfax.

The Makah neo-whaling elite attempts to build up the tribal community according to the neo-aristocratic idea of an orderly hierarchical society where status is inherited: the whale is a metaphor of this orderly society, similar to the Nootkan ancient society, even though the slaves no longer exist. Makah ideologists demand the recognition of their 'cultural rights' as a means to heal 'social ills' whose cause is not attributed to the different access to political power and means of production, but to a cultural message to be cured with restoration of the 'traditional' social order through the resumption of whaling.

\section{Conclusion}

Historically the Makah organized them in small chiefdoms, whose society was stratified in aristocratic lineages, commoners and slaves. Status was ascribed by birth and validated by potlatching. Ruling class control was economic, political, and ideological, although far from complete and not always effective. Things changed profoundly, however, in the mid-nineteenth century: After smallpox epidemic and the 1855 treaty many slaves born in the tribe purchased their freedom and a number of slave men and women also married their former masters and mistresses. ${ }^{5}$ The children of such marriages were considered half slaves and the stigma of these ascendants has not yet disappeared and is matter of much gossip. The introduction

\footnotetext{
${ }^{12} \mathrm{Cf}$. Tweedie ${ }^{45}$, Erikson ${ }^{54}$, Erikson PP, Ward H, Watchendorf K. ${ }^{53}$
} 
of a European cash economy during the heyday of the sea otter fur trade and the later advent of commercial whaling and sealing created a shift in emphasis away from whaling and associated social mechanisms. Trading with the Euro-Americans opened the door to property and chiefly privileges and being near the source of American power, the reservation agent, meant being also able to distribute favours, furthermore disrupting the old system of power. In 1924 the United States granted all American Indian people citizenship and the right to vote, an event which is still commemorated in the annual Makah Days. In 1934 the Indian Reorganization Act (IRA) gave the Makah the opportunity to develop a tribal constitution and an elected government. The Makah had stopped whaling in the early $20^{\text {th }}$ century. After more than a seventy years' gap, they petitioned the US government to represent them at the International Whaling Commission (IWC) after the grey whale was removed from the list of the endangered species. Although the Makah cannot be considered to hunt for subsistence, they can rely on the 1855 Treaty of Neah Bay with the USA which explicitly safeguards their right to whale. Hence, the US delegation aggressively petitioned the IWC on behalf of the Makah' cultural rights', after years of adamant support of the moratorium. This move created havoc among environmentalist groups and animal rights advocates, who boycotted physically the hunt. I analyzed how the Makah ruling class has been able to strengthen its hegemony on its tribal fellow citizens, controlling an economic and social crisis and imposing its 'neo-whaling' ideology as a tool of social control. However, this ideology, though accepted by most Makah and politically correct social scholars, has been challenged by green activists and above all, by the media and the public. So far the Makah killed successfully only one whale and failed the 2000 and 2001 hunts. They also lost in the federal court in 2002 and 2004, killed a whale illegally in 2007 and are presently banned from whaling.

For most of their histories the Makah have flourished and although they endured colonization, they managed to survive social and economic collapse and ferry themselves into the capitalist world. During their voyage from a group of five small chiefdoms to a single neo-tribe, they adapted their society according to two principles: kinship solidarity and family competition. Since the 1970s, forged in the Northwest fish-ins, the Makah elite has reinvented its values through the Makah Renaissance, a local ideological movement of revitalization inspired by the archaeological site of Ozette and the building of the MCRC, a tribal museum which has become the physical place of the embodiment of neo-whaling ideology. Challenged by postmodern globalizing processes, the Makah elite has espoused capitalist political and economic structures to neotraditionalist thought, according to a contemporary trend which is common to American and Canadian American Indians as well as other indigenous peoples such as the Maoris and the Hawaiians.

Ginkel Van $\mathrm{R}^{55}$ makes a rather gloomy portrait of the Makah in the early $21^{\text {th }}$ century: "Most members of the tribe live in the tiny coastal village of Neah Bay, adjacent to the Strait of Juan de Fuca. It is a relatively poor community, facing high levels of unemployment and problems including alcoholism and drug abuse. Prefab homes and trailers dominate Neah Bay, but there are also modern facilities and services, including a renowned museum and a new marina. The marina harbours over two hundred commercial and sport fishing vessels as well as pleasure craft and accommodates numerous small businesses. In many respects, the inhabitants take part in 'the American way of life', including aspects of its mass culture. They wear blue jeans and
Nikes, eat pizza, watch television, use cell phones, surf the Internet and play video games. But this, of course, does not define them as Makah. In search of who they are, some tribal members have turned to history and to the tribe's whaling history more specifically, to boost present and future identity". As a matter of fact, when a group of Italians, mostly from Bologna, went to Neah Bay in the late 1990s in order to spend what we call an 'intelligent vacation', that is culturally engaged, they surprised their Makah hosts, who felt a bit humiliated that these scions of the rich Bolognese intelligentsia considered their reservation a sort of desperate rural favela. In fact, the Makah did not perceived themselves so poor, on the contrary, political rhetoric aside, they felt their standard of living was adequate, Greg Colfax told me $^{13}$ So, van Ginkel's rather bleakly description of the reservation should be taken with a grain of salt and I do not agree completely when he says that some tribal members are pushing the whaling issue to boost present or future identity. I believe it is rather simplistic to reduce to an identitarian issue what looks more an apparently antimodern challenge to representative democracy, when actually it is a post-modern trend to call it into question ${ }^{14}$.

However, the Makah brand of neo-tribal traditionalism, albeit hegemonic within the tribe and supported by the federal government, has clashed with the notion of tradition which both new right and new left people, environmental and animal rights advocates as well as the media have entertained since the 1970s. Both the Makah and the animalist militants look at Western science for support and both sides see the world according to organic analogies, but the meanings they attach to these analogies are different. The Makah whaling elite tries to construct their tribal community according the aristocratic stance of an ordered hierarchical society: the whale is a metaphor of this ordered society, similar to the ancient Nootkan three-tiered communities, even if slaves do not exist any longer. On the other hand, environmentalist activists refer to the New Age version of the Lakota phrase "mitakuye oyasin" (all my relations), which has more to do with Gaia, the living Mother Earth and the medieval 'chain of beings.'

In complex postmodern, post-industrial globalized society, of which the Makah are members, capitalist hegemonic thought is very complex and mirrors the different interests of shifting historical blocs. Probably the Makah did not realize that putting in motion the legal mechanism in order to remove the grey whale from the endangered species list and to dust off their heirloom harpoons and whaling songs, would turn Neah Bay from a face-to-face village into a global village. They were eager to taste whale meat and were chewed up by the media. As a domestic dependent nation, as Judge Marshall put it in the $19^{\text {th }}$ century, could rely on the support of the federal government, but the Makah case demonstrates that even the government of the single superpower cannot overcome the complexities of hegemonic thought in postmodern capitalist society.

In 2002 in Anderson v. Evans (314 F.3d 2006) the United States Court of Appeals for the Ninth Circuit in San Francisco, rejected as inadequate a federal environmental assessment that the whaling had no significant impact on the local whale population and the precedent whaling could set in other areas. The appeals court panel also said the whaling violated the Marine Mammal Protection Act. Judge Marsha S. Berzon wrote for the majority sections I and II. : "While in life

${ }^{13}$ We had acted as intermediaries between the tribe and the 'intelligent' tourists.
${ }^{14}$ For example, in Italy, a large number of leftist intellectuals are proposing to
limit the right of vote so the populace cannot 'vote in the wrong way,' that is for some opposition party they do not like. 
the great whale's body may have been a real terror to his foes, in his death his ghost became a powerless panic to the world." Herman Melville, Moby Dick 262. This modern day struggle over whale hunting began when the United States granted support and approval to the Makah Tribe's ("the Tribe's") plan to resume whaling. Having reviewed the environmental assessment ("EA") prepared by the government agencies and the administrative record, we conclude that there are substantial questions remaining as to whether the Tribe's whaling plans will have a significant effect on the environment. The government therefore violated NEPA by failing to prepare an EIS before approving a whaling quota for the Tribe. We also conclude that the MMPA applies to the Tribe's proposed whale hunt." Most Makah, even many who were rather lukewarm about resuming whaling, were furious at the opinion, because it put together fiction and real people by quoting Melville's Moby Dick. They did not realize that, in the post-industrial world, symbolic production and the production of intangible goods is the trade mark of global economy and politics.

In 2010 the population of Neah Bay was made of about 1400 people, 75 percent of whom were Makah tribal members and another 1500 circa lived off the reservation. Commercial fishing, timber, tourism and sport fishing are currently the most important economic activities and as a result of the fish-ins in the 1970s, the tribe co-manages various fisheries with the state of Washington and other entities. The decline of the Pacific Northwest timber industry and salmon fisheries, however, impacted on Makah income and a casino failed to survive the first two-three years. Unemployment is 51 percent and almost 40 percent of the reservation households are below the federal poverty line at the moment. The resumption of whaling should be, according to its tribal proponents, a salve for the social wounds inflicted by historical colonialism. In her 2007 and 2012 reports Renker, ${ }^{56}$ nonMakah anthropologists, but well within neo-whaling ideology, implies that drug and alcohol abuse in the reservation are a direct result of non-whaling. As a matter of fact, the effort to resume whaling has become tied to the question of sovereignty, even if resuming whaling has been a costly endeavor (two to five million dollars, albeit partially federally funded). According to Kim, ${ }^{57}$ of the 93 percent of Makah in favor of resuming whaling, a majority cited tribal rights as a reason, while a minority cited cultural tradition and moral/spiritual benefits.

Most analyses of the Makah effort to revitalize whale hunting deal with the contrast between the 'ecological' Indian of green ideology and the 'non-ecological' one the Makah supposedly represent in green activists' propaganda. Studies also deal with on the issues of authenticity, invented traditions, etc., but very few with the consequences of a Makah neo-aristocratic restoration, supported by its neo-whaling ideology as a tool of social control, if it succeeds in being federally recognized. $\mathrm{Kim}^{58}$ makes an exception, pointing out that what whaling proponents do not speak about are the various patterns of internal domination relating to class/status and sex as well as species. The labor of slaves was essential because slaves made possible for titleholders to live and act as such. The link between social hierarchy and whaling was strong enough that whaling became increasingly infeasible when assimilation policies, disease and nonIndian competition disrupted Makah social structures. Hence whaling was substituted by the more 'egualitarian' sealing and halibut and salmon fishing. Moreover, Makah whaling reinforced traditional sex relation: women could not be chiefs and therefore could not whale and viceversa; women had to observe a number of religios norms that made the analogy between the whaler's wife (and therefore also the other women) and the preyed whale to be speared. The chief was the penetrator, the whale/woman the penetrated. "The woman was animalized, the animal feminized. The chief demonstrated his greatness by exercising mastery over whale, woman and nature." 58 Gendered aspects of whaling persisted in the 1999 successful hunt and also in the failed ones in the early 2000s. The inequality of women's involvement in the hunt was a reason offered by some of the few opponents, brave enough to speak aloud. It is a fact that the incorporated tribe, as well as access to professions and the university, has given tribal women a very important occasion to overcome traditional roles. Women can be chiefs in the elected councils, when they could not in traditional society. Most tribal officials are currently women all over Indian Country and Neah Bay is not an exception. The supporters of neo-whaling ideology represent a serious threat to current sex relations.

Different forms of democracy are advocated by chief Happynook, a most important neo-aristocratic representative of the neo-whaling movement. He mentions in the same breath hereditary rights and democracy (cf. supra: Nootkan type of liberal democracy should be "based ... upon the hereditary chiefs. ... Understanding where you fit within the universe ... creates different forms of democracy which has been given by our creator and administered through the people by the hereditary chiefs"). Yet this is not a political oxymoron impossible to propose. In fact, capitalism is not a synonym of democracy and post-modernity shows that other oxymora survive and flourish, such as Iranian theocratic democracy, Chinese Communist capitalism, etc. Hence, if the neo-whaling proponents succeed in having recognized their idea of Nootkan society, that is a post-traditional 'capitalist chiefdom,' by the federal American and Canadian governments, this achievement may have unforeseen consequences. In the name of what Charles Taylor ${ }^{1}$ calls the "politics of recognition'15 many conquests of modernity, such as universal adult suffrage, women's equal rights, equality in front of the law, etc. bestowed to the Western world by at least five centuries of Euro-American political thought and upheavals, will be put at risk. In fact, on "the basis of differential treatment" certain minorities (such as the Makah) will get the right to exclude others in order to preserve their cultural integrity, and so on."1

The highest ranking Nootkan male was the chief of an extended family: he owned all of his family wealth, both tangible and nontangible. As Drucker ${ }^{59}$ points out, the absence of a clear-cut division between chiefs and commoners was asserted by emphasizing the chief's complete control over the surplus wealth produced by his group: this control was the foundation and the expression of fundamental differences in the socio-economic status of chief and commoners. I believe that most supporters of a return to a non-denaturized form of 'traditional' government do not realize the ultimate consequences of their political goal that is a post-traditional 'capitalist chiefdom'. In fact, the achievement of this goal would jeopardize both their property and civil rights. ${ }^{60-66}$

\section{Acknowledgements}

None.

\section{Conflict of interest}

Author declares there is no conflict of interest in publishing the article.

\footnotetext{
15 "what is today called the politics of "multiculturalism."1

(elplandehiram.org/documentos/.../Politics_of_Recognition.pdf)
} 


\section{References}

1. Taylor C. The Politics of Recognition. In: A Gutmann, editors Multiculturalism: Examining the Politics of Recognition. Princeton: Princeton University Press, USA; 1992.

2. Renker AM, Gunther E. The Makah. The Handbook of North American Indians. vol. 7, Smithsonian Institution, USA; 1990.

3. Renker AM. The Makah. Encyclopedia of Native American Indians in the Twentieth Century. USA; 1994.

4. Colson E. The Makah Indians. American Anthropologist. 1953;56(5):308.

5. Swan J. The Indians of Cape Flattery, at the Entrance to the Strait of Juan de Fuca, Washington Territory. Smithsonian Contributions to Knowledge. 1870;16(8):1-106.

6. Densmore F. The Nootka and Quileute Music. Government Printing Office, USA; 1939. p. 124

7. Riley C. The Makah Indians: A Study of Political and Economic Organization. Ethnohistory. 1968;15(1):57-95.

8. Millan AD. Since Kwatyat Lived on Earth: An Examination of NuuChah-Nulth Culture History. Simon Fraser University, Canada; 1998.

9. Drucker P. The Northern and Central Nootkan Tribes. Bureau of American Ethnology, USA; 1951. p. 238.

10. Ames KM. The Evolution of Social Ranking on the Northwest Coast of North America. American Antiquity. 1981;46(4):789-805.

11. MacLeod WC. The Origin of Servile Labour Groups. American Anthropologist. 1929;31(1):89-113.

12. Ruyle EE. Slavery, Surplus and Stratification on the Northwest Coast: The Ethnoenergetics of an Incipient Stratification System. Current Anthropology. 1973;14(5):603-631.

13. Renker AM (nd) The Makah Tribe: People of the Sea and the Forest University of Washington, USA.

14. Wike JA. Social Stratification Among the Nootka. Ethnohistory. 1958;5(3):219-241.

15. Mackenzie A. Voyages from Montreal, on the River St. Laurence, Through the Continent of North America, to the Frozen and Pacific Oceans; In the Years 1789 and 1793. Toronto. The Courier Press LTD, Canada; 1801. p. 374-375

16. Arima, Eugene, Dewsirst, et al. Nootkans of Vancouver Island. Handbook of North American Indians (Vol. 7), Smithsonian Institution, USA; 1990. p. 400 .

17. Ruby RH, Brown JA. Indian Slavery in the Pacific Northwest. Arthur H Clark Company, USA; 1993. p. 336.

18. Ruby RH, Brown JA. Indians of the Pacific Northwest. A History, University of Oklahoma Press, USA; 1988. p. 304.

19. Nieboer HJ. Slavery as an Industrial System. Ethnological Researches. Free Library of Philadelphia, USA, 1971.

20. Collins CC. Subsistence and Survival. The Makah Indian Reservation, 1855-1933. University of Washington, USA; 1996. p. 180.

21. Goodman L. Traditional Music in Makah Life. In: Wright RK, editor. A Time of Gathering. Native Heritage in Washington State. Burke Museum and University of Washington Press, USA; 1991.

22. Codere H. Fighting with Property: A Study of Kwakiutl Potlatching and Warfare. American Anthropologist. 1950;53(4):545-546.

23. Codere H. The Amiable Side of Kwakiutl Life: The Potlatch and the Play Potlatch. American Anthropologist. 1956;58(2):334-351.
24. Boas F. The Social Organization and the Secret Societies of the Kwakiutl Indians. Report of the U.S. National Museum for 1895, Washington, USA; 1987. p. 311-738.

25. Boas F. Kwakiutl Ethnography. In: Codere H, editors. American Anthropologist. 1966;72(3):629-632.

26. Benedict R. Patterns of Culture. Houghton Mifflin, USA; 1934.

27. Barnett HG. The Nature of the Potlatch. American Anthropologist. 1938;40(3):349-358.

28. Mauss M, Pritchard EE. Forms and Functions of Exchange in Archaic Societies. The gift, Cohen \& West Ltd, USA; 1966.

29. Drucker P, Heizer R. To Make My Name Good: A Reexamination of the Southern Kwakiutl Potlatch. American journal of sociology. 1969;74(5):p.543.

30. Jonaitis A, Cole D. Chiefly Feasts: The Enduring Kwakiutl Potlatch Seattle. Art Journal. 1992;51(4):91-93.

31. Rosman A, Rubel PG. Feasting with Mine Enemy: Rank and Exchange among Northwest Coast Societies. American Anthropologist. 1971;75(2):415-417.

32. Rubel, Paula G, Abraham R. The Evolution of Exchange Structures and Ranking: Some Northwest Coast and Athapaskan Examples. Journal of Anthropological Research. 1983;39(1):1-25.

33. Jewitt JR. A Narrative of the Adventures and Sufferings of John R. Jewitt, only survivor of the crew of the ship Boston, during a captivity of nearly three years among the savages of Nootka Sound: with an account of the manners, mode of living, and religious opinions of the natives. Thomas Tegg. USA; 1820. p. 208

34. Sapir E. The Social Organization of the West Coast Tribes. Proceedings and Transactions of the Royal Society of Canada for 1915. 1916;9(2):355-374.

35. Clutesi G. Potlatch. Gray's Publishing, USA; 1969

36. James GR. The Maritime Fur Trade of the Northwest Coast. Otter Skins, Boston Ships and China Goods, University of Washington Press, USA; 1992. p. 452.

37. Kirk R. The Makah, Nuu-chah-multh, Southern Kwakiutl and Nuxalk Tradition and Change on the Northwest Coast. University of Michigan Library, USA; 1986. p. 256.

38. Webb RL. On the Northwest: Commercial Whaling in the Pacific Northwest, 1790-1967. University of British Columbia Press, USA; 1988.

39. Sullivan R. A Whale Hunt. How A Native American Village Did What No One Thought It Could. Simon \& Schuster, New York, USA; 2000.

40. Gluckman M. Gossip and Scandal. Current Anthropology. 1963;4(3):307-316.

41. Hogan L. Silencing Tribal Grandmothers-Traditions, Old Values At Heart Of Makah's Clash Over Whaling. The Seattle Times. 1996.

42. Happynook TM. Indigenous Self Determination, Accountability and Liberal Democracy. Turtle Islands Network, USA.

43. Black M. Huupukwanum-Tupaat. Out of the Mist: treasures of the Nuuchah-nulth Chiefs. Royal British Columbia Museum, Canada; 1999. p. 160 .

44. Happynook TM. Whaling and the Nuu chah-nulth People. Turtle Island Native Network Aboriginal News \& Information. USA; 2004.

45. Happynook TM. Securing Nuu Chah Nulth Food, Health and Traditional Values through the Sustainable Use of Marine Mammals. Turtle Islands Network, USA; 2001. 
46. Busatta S.The Jaguar: The Aztecs' dark Side of Power. Antrocom 2007;(3)1:5-7.

47. Hale DG. Analogy of the Body Politic. In: Wiener PP, editors. The Dictionary of the History of Ideas. New York: Charles Scribner's Sons Publishing company, USA; 2003. p. 67.

48. Harkin M. Whales, Chiefs and Giants: An Exploration into Nuu-ChahNulth Political Thought. Ethnology. 1998;37(4):317-332.

49. Tweedie AM. Drawing Back Culture. The Makah Struggle for Repatriation. University of Washington Press, USA; 2002.

50. Meissner D. Spiritual Bond Between Killer Whale and West Coast Aboriginals Runs Deep. Victoria Times Colonist. 2004.

51. Rata E. A Political Economy of Neotribal Capitalism. Lexington Books, USA; 2000.

52. Friedman J. Myth, History and Political Identity. Cultural Anthropology. 1992;7(2):194-210.

53. Friedman J. Cultural Identity and Global Process. Sage, England; 1994. p. 288.

54. Friedman J. Class Formation, Hybridity and Ethnification in Declining Global Hegemonies. In: Olds K, Dickin P, et al. editors, Globalization and the Asia Pacific, England; 1998.

55. Strathern M. The Gender of the Gift, Berkeley: University of California Press, USA; 1988.

56. Coe RT. Lost and Found Traditions: Native American Art 1965-1985. University of Washington Press, 1986. p. 288.

57. Erikson PP, Ward H, Watchendorf K. Voices of a Thousand People. The Makah Cultural and Research Center. University of Nebraska Press, USA; 2002. p. 264.

58. Erikson PP. Awhaling We Will Go: Encounters of Knowledge and Memory at the Makah Cultural Center. Cultural Anthropology. 1999;14(4):556-583.
59. Ginkel Van R. The Makah Whale Hunt and Leviathan's Death: Reinventing Tradition and Disputing Authenticity in the Age of Modernity. ETNOFOOR XVII(1/2): 2004;58-89,60.

60. Kim CJ. Dangerous Crossings: Race, Species and Nature in a Multicultural Age. Journal of Asian American Studies. 2015;19(1):127-130.

61. Kim CJ. Dangerous Crossings: Race, Species, and Nature in a Multicultural Age, Cambridge University Press, USA; 2015.

62. Drucker P. The Northern and Central Nootkan Tribes. Bureau of American Ethnology. American Anthropologist. 1952;54(2): p. 144.

63. Erikson PP. Voices of a Thousand People. The Makah Cultural and Research Center. Nebraska University Press, USA; 2002.

64. Friedman J. Indigenous Struggles and the Discreet Charm of the Bourgeoisie. The Australian Journal of Anthropology. 1999;10(1):1-14.

65. Marino C. The History of Northwestern Washington since 1846. The Handbook of North American Indians. vol 7, Smithsonian Institution, USA; 1990.

66. Rata E. Late Capitalism and Ethnic Revivalism: A New Middle Age. Anthropological Theory. 2003;3(1):43-63.

67. Waterman TT. The Whaling Equipment of the Makah Indians. University of Washington Publications in political and Social Science. 1920;1(1):1-67

68. Wilson PJ. Filcher of Good names: An Enquiry into Anthropology and Gossip. Man. 1974;9(1):93-102.

69. Wright R. A Time of Gathering. Native Heritage in Washington State. In: Wright RK, editors. Burke Museum and University of Washington Press, USA; 1991. 